DOI

\title{
ОНОВЛЕННЯ НАВЧАЛЬНО-МЕТОДИЧНИХ ВИДАНЬ - ВАЖЛИВА СКЛАДОВА ОРГАНІЗАЦІЇ НАВЧАЛЬНОГО ПРОЦЕСУ НА КАФЕДРІ ПЕДІАТРІї
}

\author{
В. О. Боднарчук \\ Львівський національний медичний університет імені Данила Галицького
}

\begin{abstract}
THE UPDATING OF TEACHING AND LEARNING PUBLICATIONS AS A SIGNIFICANT CONSTITUENT OF EDUCATIONAL PROCESS ORGANIZATION IN THE DEPARTAMENT OF PEDIATRICS
\end{abstract}

\section{O. Bodnarchuk}

\author{
Lviv National Medical University by Danylo Halytskyi
}

\begin{abstract}
У статті висвітлено важливість оновлення навчально-методичних видань для покращення організації навчального процесу у вищих медичних навчальних закладах. Обгрунтовано доцільність видання навчально-методичних посібників “Диференційна діагностика найбільш поширених захворювань ендокринної системи у дітей” та “Алергічні захворювання у дітей. Частина 1. Бронхіальна астма” для студентів та викладачів медичних ВНЗ додипломної освіти; зазначено їх актуальність та оригінальність. Проаналізовано зміни в типовій програмі з дисципліни “Педіатрія” для студентів VI курсу медичного факультету за спеціальністю “Педіатрія” (2014) та клінічних протоколах МОЗ України.

The article adduces the significance of teaching and learning publications updating for the enhancement of educational process organization at higher medical educational institutions. It gives the grounds for publication of teaching and learning textbooks "Differential Diagnostics of the Most Common Endocrine System Diseases in Children” and "Allergic Diseases in Children. Part 1. Bronchial Asthma" for the pre-graduate students and lecturers of higher medical educational institutions; its topicality and originality have been proved. The articles analyses the changes made in the standard academic program for the discipline "Pediatrics" for the fourth-year students of medical faculty by speciality "Pediatrics" (2014) and clinical protocols of the Ministry of Healthcare of Ukraine.
\end{abstract}

Вступ. Одним із пріоритетних напрямків розвитку вищого навчального закладу є організація інформаційної та видавничої діяльності, популяризація досягнень науки вищої школи через засоби масової інформації, мережу Інтернет. Оприлюднення результатів наукової та навчально-методичної роботи викладачів університету через друковані видання залишається пріоритетним над електронними.

Якість надання медичної допомоги населенню насамперед залежить від рівня підготовки лікаря, тому найважливішою проблемою сучасної освіти залишається якісна підготовка медичних кадрів. Враховуючи це, сьогодні залишаються актуальними зміни навчальних програм, оновлення навчально-методичних видань. Існують такі види неперіодичних видань за інформаційними ознаками: посібник, наочний посібник, практичний посібник, навчальний посібник, навчально-методичний посібник, підручник, методичні рекомендації, прак-

() В. О. Боднарчук тикум, словник, термінологічний словник, курс лекцій, текст лекцій, конспект лекцій, навчальна програма, монографія, автореферат дисертації, препринт, тези доповідей наукової конференції, матеріали конференції, збірник наукових праць, практичний порадник [3].

Слід пригадати, що посібник - видання, призначене на допомогу в практичній діяльності чи в оволодінні навчальною дисципліною; наочний посібник - видання, зміст якого передається, в основному, зображувальними засобами; практичний посібник - виробничо-практичне видання, призначене практичними працівниками для оволодіння знаннями та навичками при виконанні будь-якої роботи, операції, процесу; навчальний посібник - навчальне видання, що доповнює або частково/повністю замінює підручник та офіційно затверджене як таке; навчальнометодичний посібник - навчальне видання з методики викладання навчальної дисципліни (ії розділу, частини) або з методики виховання; практичний порадник - видання, розраховане на самостійне оволо- 
діння будь-якими виробничо-практичними навичками; підручник - навчальне видання з систематизованим викладом дисципліни (їі розділу, частини), що відповідає навчальній програмі та офіційно затверджене як таке; методичні рекомендації - навчальне або виробничо-практичне видання роз'яснень 3 певної теми, розділу або питання навчальної дисципліни, роду практичної діяльності, з методикою виконання окремих завдань, певного виду робіт, а також заходів [3].

В останнє десятиліття ми відмічаємо невпинне збільшення поширеності ендокринної патології. Згідно з даними М. В. Гульчія, за період із 2003 по 2012 рік розповсюдженість ендокринних захворювань зросла із 700 до 869,3 випадку на 10 тис. населення України. У структурі ендокринної патології в Україні переважають захворювання щитоподібної залози (Щ3) (46,67 \%), цукровий діабет (31,88 \%) та ожиріння, тоді як на інші ендокринні захворювання припадає загалом лише 8 \% (акромегалія, гіпопаратиреоз, нецукровий діабет, хвороба Іценка - Кушинга, Аддісонова хвороба, феохромоцитома тощо). На жаль, спостерігається гіподіагностика цих рідкісних захворювань, як наслідок переважна більшість таких пацієнтів не отримує необхідного лікування.

Сьогодні зростає рівень розповсюдженості і захворюваності на тиреотоксикоз (у 2012 році 15,1 та 1,61 випадків на 10 тис. населення відповідно (М. В. Гульчій, 2013). Збільшення розповсюдженості автоімунного тироїдиту, яке зумовлене порушенням з боку імунної системи, можна пов’язати 3 постійним погіршенням екологічної ситуації у світі.

Після аварії на ЧАЕС спостерігається зростання захворюваності серед дітей на доброякісні та злоякісні пухлини ЩЗ. Захворюваність на рак ЩЗ становить сьогодні 6,6 випадку на 100 тис. населення. Тактика лікування цієї патології добре відпрацьована і на сьогодні п’ятирічне виживання хворих із високодиференційованим раком ЩЗ становить 98 \% (М. В. Гульчій, 2013). Помилки в лікуванні раку ЩЗ пов'язані в більшості випадків із неправильним визначенням типу раку. Тому дуже важливо навчитись правильно та вчасно діагностувати ці захворювання лікарям усіх медичних спеціальностей, щоб надати належну лікарську допомогу.

Сьогодні також спостерігається гіподіагностика бронхіальної астми (БА) у дітей і в той же час зростання алергопатології. В 2006 році запропоновано поділ БА на контрольовану (К БА), част- ково контрольовану (ЧК БА) та неконтрольовану (НК БА). Зараз на ринку України і в новому клінічному протоколі МO3 [6] відсутні протизапальні препарати натрію кромоглікат (інтал) та натрію недокроміл (тайлед), а в алгоритмі лікування атопічної БА та АР пропонується новий препарат “Омалізумаб”; також для діагностики та лікування БА застосовуються нові алгоритми лікарської тактики [2, 6].

Все вищезазначене і стало причиною оновлення навчально-методичних видань. Метою написання посібників “Диференційна діагностика найбільш поширених захворювань органів ендокринної системи у дітей” та “Алергічні захворювання у дітей. Частина 1. Бронхіальна астма у дітей” було представити сучасні засади навчально-методичного проектування практичних занять, враховуючи зміни в типовій програмі та клінічних протоколах МОЗ України [6, 7], допомогти студенту якісно самостійно підготуватися до практичного заняття, перевірити рівень засвоєння теоретичного матеріалу, вирішивши наведені ситуаційні завдання та задачі різного рівня, а також викладачам кафедр педіатрії вищих медичних навчальних закладів IV рівня акредитації надати сучасні методично обгрунтовані рекомендації щодо проведення практичного заняття [4, 5].

Основна частина. Згідно з типовою програмою у Львівському національному медичному університеті імені Данила Галицького з дисципліни “Педіатрія” студенти V курсу медичного факультету вивчають такі важливі теми з дитячої ендокринології, як цукровий діабет у дітей, захворювання ЩЗ у дітей, захворювання гіпоталамо-гіпофізарної системи та статевих залоз у дітей, захворювання надниркових залоз (50 \% модуля “Хвороби системи крові та ендокринної системи у дітей”).

На VI курсі для студентів-педіатрів згідно з навчальною програмою з 2014 року виділено 9 тем 3 дитячої ендокринології (табл. 1).

У навчально-методичному посібнику “Диференційна діагностика найбільш поширених захворювань органів ендокринної системи у дітей” на прикладі деяких з цих тем розглянуто застосування новітніх технологій у медичній освіті. Він побудований за традиційною схемою, складається зі вступу, переліку скорочень, 4 розділів (кожний розділ-це окрема тема заняття), списку літератури та додатків. Написано всі розділи відповідно до структури заняття на 6 курсі, де виділено три етапи: підготовчий, основний, підсумковий.

Наведені графологічні схеми з еталонами відпо- 
Таблиця 1. Теми, які вивчаються на VI курсі медичного факультету з дитячої ендокринології на кафедрі педіатрії

\begin{tabular}{|c|c|}
\hline Було у програмі & Зміни з 2014 року у навчальній програмі \\
\hline \multirow[t]{2}{*}{$\begin{array}{l}\text { Диференційна діагностика цукрового } \\
\text { діабету у дітей }\end{array}$} & $\begin{array}{l}\text { Диференційна діагностика синдрому гіперглікемії, цукровий діабет } \\
\text { у дітей }\end{array}$ \\
\hline & $\begin{array}{l}\text { Диференційна діагностика гострих та хронічних ускладнень } \\
\text { цукрового діабету у дітей; синдром гіпоглікемії }\end{array}$ \\
\hline $\begin{array}{l}\text { Диференційна діагностика патології } \\
\text { ЩЗ у дітей }\end{array}$ & $\begin{array}{l}\text { Диференційна діагностика синдрому зоба, гіпо- та гіпертиреозу у } \\
\text { дітей }\end{array}$ \\
\hline \multirow{2}{*}{$\begin{array}{l}\text { Диференційна діагностика захворювань } \\
\text { надниркових залоз у дітей }\end{array}$} & Диференційна діагностика захворювань надниркових залоз у дітей \\
\hline & $\begin{array}{l}\text { Диференційна діагностика захворювань гіпоталамо-гіпофізарної } \\
\text { системи у дітей }\end{array}$ \\
\hline \multirow{2}{*}{$\begin{array}{l}\text { Диференційна діагностика порушень } \\
\text { зросту та статевого розвитку у дітей }\end{array}$} & Диференційна діагностика порушень зросту у дітей \\
\hline & $\begin{array}{l}\text { Диференційна діагностика синдрому передчасної статевої зрілості, } \\
\text { порушення статевого розвитку у дітей }\end{array}$ \\
\hline \multirow[t]{2}{*}{$\begin{array}{l}\text { Диференційна діагностика ожиріння у } \\
\text { дітей }\end{array}$} & $\begin{array}{l}\text { Диференційна діагностика ожиріння у дітей, метаболічний } \\
\text { синдром }\end{array}$ \\
\hline & $\begin{array}{l}\text { Диференційна діагностика білково-енергетичної та вітамінної } \\
\text { недостатності у дітей. Синдром гіпо- та гіперпаратиреозу }\end{array}$ \\
\hline
\end{tabular}

віді допоможуть студенту перевірити знання диференційної діагностики ендокринних захворювань, підвищують їх зацікавленість у самостійній підготовці, а викладачу в об’єктивному оцінюванні на різних етапах заняття (підготовчому та заключному).

Вагому роль сьогодні відіграє самостійна робота студента, в чому йому допоможе наведена в посібнику орієнтовна карта для роботи з літературою, перелік рекомендованої літератури (основної, додаткової), електронні джерела до кожної теми.

Рекомендовано для заохочення студентів до наукового пошуку задавати готувати інформаційне повідомлення, презентацію на тему, яка їх найбільше зацікавила та $є$ дотичною до теми практичного заняття чи є наведена в пункті 2.4 посібника, після чого слід майбутньому педіатру представити підготовлений матеріал своїм одногрупникам на занятті під контролем викладача. Це допоможе викладачеві побачити студентів в дискусії та виборі найбільш обдарованих, із здібностями до наукової роботи. 3 метою заохочення студентів до участі в такій роботі йому слід нараховувати бали (додавати до оцінки за заняття).

У посібнику підкреслено необхідність сформувати у студентів основні уявлення про важливість дотримання принципів деонтології та лікарської етики при обстеженні хворої дитини і проведенні лікувально-діагностичних маніпуляцій, спілкуванні з батьками хворого.

При проведенні підготовчого етапу заняття (20 \% часу), крім організаційних питань, визначення навчальних цілей, відбувається контроль вихідного рівня знань, навиків і вмінь, при якому запропоновано, крім індивідуального теоретичного опитування, тестового контролю, вирішення типових задач, давати заповнювати студенту структурологічні схеми. Типові задачі - це задачі, коли спосіб розв'язання описаний у рекомендованій літератуpi i є всі необхідні дані для їі вирішення студенту. Їх роль: умовний місток між теорією і задачами нетиповими. Вони формують рішення стандартних ситуацій, коли однозначна схема відповіді, план діагностики та лікування.

При формуванні професійних вмінь та навичок (основний етап - 60 \% часу) рекомендується проводити практичний тренінг у відділенні лікарні, вирішувати типові та нетипові задачі. На цьому етапі студент оволодіває навиками складання генеалогічного дерева, обстеження дитини з ендокринною патологією, методикою проведення інструментальних досліджень, методами доставки ліків, методикою розрахунків доз препаратів. Йому в цьому помагає наведений у посібнику алгоритм виконання практичних навичок. Студент вчиться проводити курацію і складати план обстеження хворого, проводити діагностику та диференційну діагностику, визначати план лікування дитини. Текстові нетипові ситуаційні задачі сприяють розвитку логічного клінічного мислення майбутніх 
лікарів, вони можуть бути без достатньої кількості даних, з надлишковими даними, з частково невірними даними, передбачати декілька варіантів вирішення, описувати атипову клініку чи супутні захворювання, потребувати складної диференційної діагностики чи невідкладної допомоги, вимагати пошуку професійних помилок.

Рекомендується в навчальному процесі широко використовувати сучасні інтерактивні технології: при відвідуванні студентами пацієнта, детально розглядаючи клінічну ситуацію дитини, їі анамнез, застосовувати викладачу “кейс метод”, що передбачає одночасну спільну роботу студентів, поділених на підгрупи, обговорення проблеми в загальному колі; дискусійні методи (студенти між собою, студенти з викладачем).

У випадку відсутності пацієнта з патологією за темою заняття слід використовувати метод “рольової гри”, коли студенти можуть застосовувати свої знання як для вирішення клінічної задачі в якості “лікаря”, так і створити свою клінічну ситуацію, перебуваючи у ролі “пацієнта”. Розігрування ролей створює сприятливий для навчання клімат, оскільки вся група бере активну участь в інсценуванні реальних ситуацій, імітує взаємини між лікарем і пацієнтом, а також між лікарями різних спеціальностей, дотримання принципів деонтології, лікарської етики, вміння ведення дискусії, критичної самооцінки.

Важливо в ході заняття навчити студента комплаєнсу з пацієнтом та його рідними [1]. Слід не забувати, що клінічне мислення формується в процесі навчання студента біля ліжка хворого, якого не можуть замінити фантоми, відеоролики чи підготовлені артисти, адже вивчення медицини заочно неможливо. Вивчаючи медицину, без контакту з пацієнтом, у студента не може сформуватись клінічне спілкування. Враховуючи особливості кожного хворого, це спілкування повинно проходити при обов’язковому контролі зі сторони викладача.

На підсумковому етапі заняття (20 \% часу) відбувається контроль та корекція рівня практичних навичок та професійних вмінь, підведення підсумків заняття: теоретичного, практичного, організаційного (підсумкове оцінювання студентів за критеріями знань, навиків, вмінь), задається домашнє завдання. На цьому етапі контроль практичних навиків здійснюється біля ліжка хворого і включає індивідуальний контроль практичних навиків та їх результатів, а контроль професійних вмінь включає аналіз та оцінку результатів клінічної роботи студентів, рішення нетипових задач, завдань.

Згідно з типовою програмою з дисципліни “Педіатрія” студенти IV курсу медичного факультету вивчають такі важливі теми з дитячої алергології, як атопічний дерматит та кропив'янка, набряк Квінке, алергічний риніт, атопічний марш, БА. Ці теми входять до модуля "Найбільш поширені соматичні захворювання”. На прикладі викладання теми “Бронхіальна астма у дітей” розглянуто застосування новітніх технологій у медичній освіті, які висвітлені в навчально-методичному посібнику “Алергічні захворювання у дітей. Частина 1. Бронхіальна астма у дітей”.

Пропонується в посібнику при проведенні підготовчого етапу заняття здійснювати контроль вихідного рівня знань, навиків і вмінь традиційними методами та шляхом заповнення структурологічних схем, вирішення кросфордів (наводжу приклади нижче).

Прошу розв'язати кросворд “Бронхіальна астма у дітей”:

Запитання по горизонталі:

1. Підвищена відповідь бронхів на специфічні і неспецифічні стимули?

2. Один із клінічних симптомів БА у дітей?

3. Ускладнення, яке може розвинутись у дітей 3 БА?

4. Муколітичний засіб, що дозволено використовувати у небулайзерах?

5. 3 якого віку можна застосовувати дозований сухопорошковий інгалятор у дітей з БА?

6. Якщо результат за даними АСТ - тесту 19 балів, тоді у дитини БА вважається?

7. Комбінований препарат, що є сполученням фенотеролу та іпратропіуму броміду?

8. Який тип вентиляційної недостатності у дитини з БА, якщо показники спірометричного дослідження: ЖЕЛ<ОФВ $<$ ОФВ $/$ ЖЛЛ?

9. 3 якого віку можна у дітей з БА використовувати інгаляційні $\beta_{2}$-агоністи тривалої дії?

10. 3 якого віку у дітей для контролю БА можна застосовувати пероральні метилксантини сповільненого вивільнення (тривалої дії) як додаткову терапію до ІГКС?

11. ІГКС, що використовують для базисного лікування БА у дітей?

Запитання по вертикалі:

1. Алерген тваринного походження, що має значення у розвитку БА?

2. Алерген рослинного походження, що має значення у розвитку БА?

3. 3 якого віку дітям можна проводити комп’ютерну 
спірометрію?

4. Який препарат використовують для проведення тесту з бронхолітиком?

5. Інгаляційний кортикостероїд, що дозволений для використання у небулайзерах і зареєстрований в Україні?

6. Який агоніст $\beta_{2}$-адренорецепторів дозволений для використання у небулайзерах?

7. Препарат, який призначають як додаткову контролюючу терапію дітям з 12 років за важкого перебігу атопічної БА, яка не контролюється незважаючи на лікування відповідно до V кроку терапії?
8. При якому ступені важкості перебігу БА у дитини ОФВ $60-80$ \%; добові коливання ПОШВ або ОФВ $>30 \%$ ?

9. Який тип вентиляційної недостатності у дитини, якщо показники спірометричного дослідження наступні: ЖЕЛ>ОФВ $>$ > ОФВ ${ }_{1} /$ ЖЛ?

10. Який антилейкотрієновий препарат застосовують у терапії дітей з БА?

11. ІГКС, що використовується для базисної терапії у дітей з БА?

Еталон відповіді:

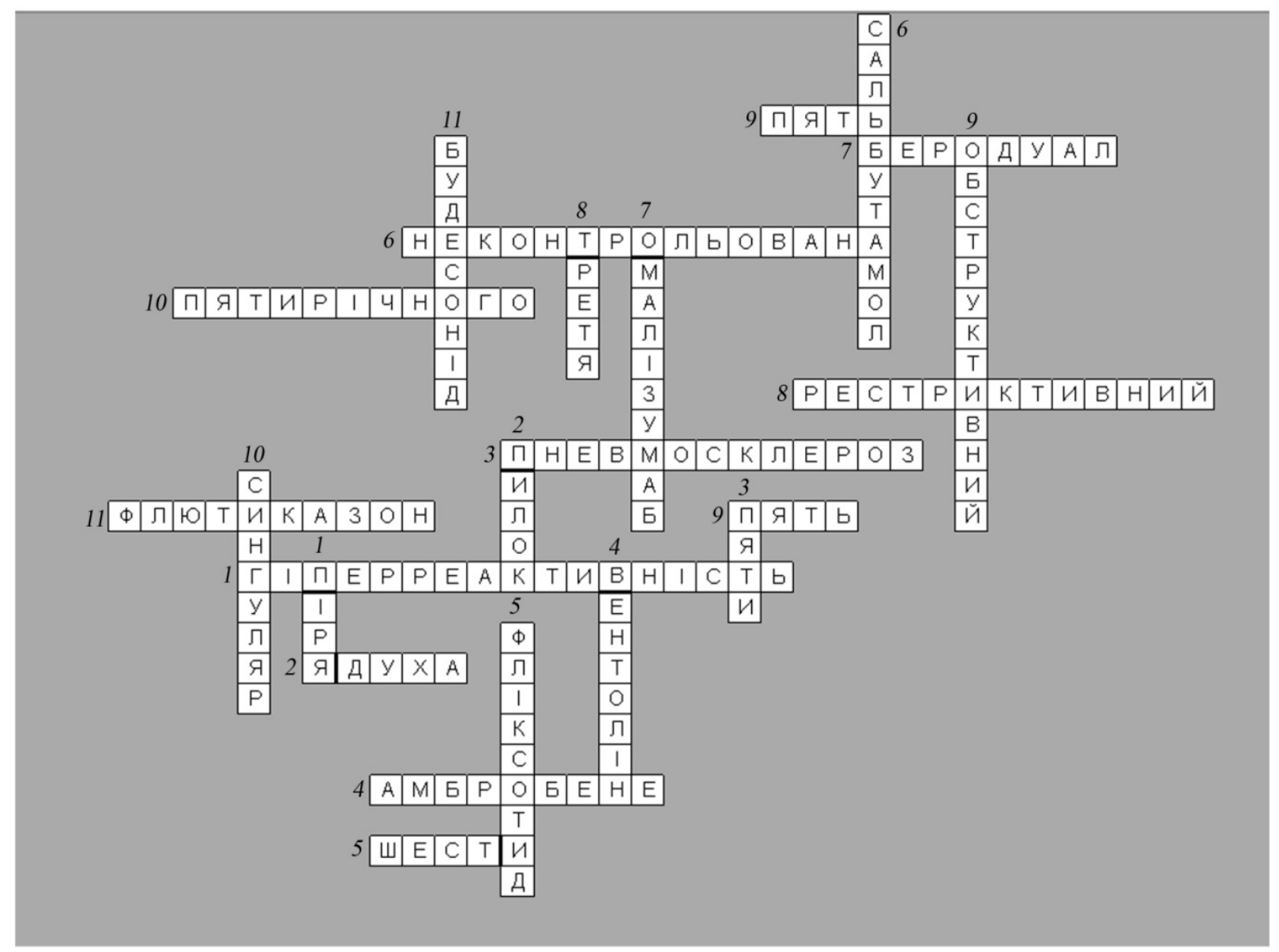

Заповніть графологічну схему “Рівні контролю БА у дітей”.

\begin{tabular}{|l|l|l|l|}
\hline \multicolumn{1}{|c|}{ Характеристики } & К БА & ЧК БА & НК БА \\
\hline Денні с-ми & & & \\
\hline Обмеження & & & \\
активності & & & \\
\hline Нічні с-ми & & & \\
\hline Необхідність у & & & \\
швидкодіючих & & & \\
інгаляторах & & & \\
\hline ОФВ1/ПОШ & & & \\
\hline Загострення & & & \\
\hline
\end{tabular}


Еталон відповіді:

\begin{tabular}{|c|c|c|c|}
\hline Характеристики & К БА (всі ознаки) & ЧК БА (одна ознака) & НК БА \\
\hline Денні симптоми & $\begin{array}{l}\text { Немає (2 або менше } \\
\text { на тиждень) }\end{array}$ & $\begin{array}{l}\text { Більше ніж } 2 \text { рази } \\
\text { тиждень }\end{array}$ & \multirow{5}{*}{$\begin{array}{l}\text { Протягом тижня три або } \\
\text { більше симптомів, що } \\
\text { погано контролюються }\end{array}$} \\
\hline Обмеження активності & Немає & Є - будь якого прояву & \\
\hline Нічні симптоми & Немає & Є - будь якого прояву & \\
\hline $\begin{array}{l}\text { Необхідність у швидкодіючих } \\
\text { інгаляторах }\end{array}$ & $\begin{array}{l}\text { Немає (2 або менше } \\
\text { на тиждень) }\end{array}$ & $\begin{array}{l}\text { Більше ніж } 2 \text { рази на } \\
\text { тиждень }\end{array}$ & \\
\hline ОФВ1/ПОШ & Нормальна & Менше 80 \% & \\
\hline Загострення & Немає & Одне чи більше на рік & Більше одного на рік \\
\hline
\end{tabular}

При формуванні професійних вмінь та навичок (основний етап) слід проводити практичний тренінг в алергологічному відділенні лікарні і тренінг у вирішенні типових, нетипових задач. На цьому етапі студент повинен оволодіти навиками обстеження дитини із БА, ознайомитись 3 методикою проведення комп’ютерної спірометрії, пікфлоуметрії, інгалювання ліків, методикою розрахунків доз препаратів. Йому в цьому допоможе представлений в посібнику алгоритм виконання практичних навичок. Студент вчиться проводити курацію і складати план обстеження хворого на БА, проводити діагностику та диференційну діагностику БА, визначати план лікування дитини. При роботі з пацієнтом рекомендується застосовувати астма контроль тест (АСТ), представлений у додатках посібника, який допоможе студенту краще зрозуміти поняття контролю БА.

На підсумковому етапі заняття, коли відбувається контроль та корекція рівня практичних навичок та професійних вмінь, підведення підсумків заняття, задавання домашнього завдання рекомендується у посібнику, крім нетипових задач, вирішувати ситуаційні завдання, зокрема завдання з АСТ, що дасть змогу перевірити засвоєння розуміння контролю БА, інші ситуаційні завдання для перевірки вміння студента визначати гіперреактивність бронхів за допомогою тесту з ДФН та ін. (один приклад наведений нижче).

Ситуаційне завдання.

Дитина віком 13 років, яка хворіє на БА, прийшла з мамою на контрольний огляд до лікаря, де їй було запропоновано заповнити тест, який включав 5 запитань:

1. Як часто протягом останніх 4-х тижнів БА не дає змогу дитині виконувати звичні обов'язки (у школі чи вдома)?

Оцінка: завжди (1 бал), дуже часто (2 бали), іноді (3 бали), рідко (4 бали), ніколи (5 балів).
2. Як часто протягом останніх 4-х тижнів спостерігалася задишка?

Оцінка: частіше одного разу на день (1 бал), раз на день (2 бали), 3-6 разів на тиждень (3 бали), $1-2$ рази на тиждень (4 бали), задишки не було (5 балів).

3. Як часто протягом останніх 4-х тижнів дитина пробуджувалася вночі або під ранок (швидше, ніж зазвичай) унаслідок проявів БА (свистяче дихання, кашель, задишка, стискання в ділянці грудної клітки)?

Оцінка: 4 ночі на тиждень або частіше (1 бал), 2-3 ночі на тиждень (2 бали), раз на тиждень (3 бали), 1-2 рази протягом 4-х тижнів (4 бали), таких випадків не було зовсім (5 балів).

4. Як часто протягом останніх 4-х тижнів була потреба в застосуванні $\beta_{2}$-агоністів швидкої дії?

Оцінка: 3 рази на день або частіше (1 бал), 1-2 рази на день (2 бали), частіше 3 разів на тиждень (3 бали), 1 раз на тиждень або рідше (4 бали), не було потреби (5 балів).

5. Як Ви оцінили контроль своєї астми протягом останніх 4-х тижнів?

Оцінка: астма зовсім не контролюється (1 бал), слабо контрольована (2 бали), помірно контрольована (3 бали), добре контрольована (4 бали), повністю контрольована (5 балів).

Загальна сума оцінок склала 17 балів $(3+4+4+3+3)$

Про що свідчать ці результати?

Еталон відповіді:

Було запропоновано заповнити АСТ. У разі загальної суми оцінок у 25 балів реєструється К БА, 20-24 бали - задовільний показник (ЧК БА), нижче 20 балів - НК БА. Отже, у дитини НК БА, слід провести корекцію базисної терапії, виявити і лікувати супутню патологію та провести пошук додаткових раніше неврахованих тригерних чинників, покращити співпрацю з пацієнтом (освітня індивідуальна робота під 
час кожного візиту, забезпечення спеціальною літературою).

Висновок. Наведені у навчально-методичних посібниках новітні технології та традиційні ме-

\section{Список літератури}

1. Алгоритм спілкування студентів (лікарів) з пацієнтами: методичні рекомендації / [укл.: Л. Я. Ковальчук, I. Р. Мисула, Н. Є. Лісничук та ін.]. - Тернопіль : Укрмедкнига, 2009. - 40 с.

2. Беш Л. В. Вивчення ефективності застосування покрокового алгоритму лікарської тактики у дітей $з$ неконтрольованою бронхіальною астмою / Л. В. Беш, В. О. Боднарчук // Здоровье ребенка. - 2010. - № 3. C. 8-13.

3. Методичні рекомендації щодо структури, змісту та обсягів наукових та навчальних видань викладачів і студентів УДПУ / [укл. О. О. Ярошинська]. - Умань, 2010. - 112 с.

4. Мілерян В. Є. Методичні основи підготовки та проведення навчальних занять у медичних вузах. Методичний посібник для слухачів ФПК первинних циклів / В. Є. Мілерян. - К., 2006. - 80 с. тоди викладання повинні покращити організацію навчального процесу, підвищити формування професійних навичок у студентів, покращити їх успішність та мотивацію.

5. Мілерян В. Є. Проектування кредитно-модульної системи організації навчального процесу. Методичні рекомендації для слухачів ФПК повторних циклів / В. Є. Мілерян - К., 2008. - 16 с.

6. Наказ МОЗ України № 868 від 08.10.2013 р. “Уніфікований клінічний протокол первинної, вторинної (спеціалізованої) медичної допомоги “Бронхіальна астма у дітей” [Електронний ресурс]. - Режим доступу: http: www.moz.gov.ua.

7. Протокол Міністерства охорони здоров’я України № 55 від 03.02.2009 р. про надання медичної допомоги “Дитяча ендокринологія” [Електронний ресурс]. - Режим доступу : http // www. moz. gov. ua.

Отримано 18.06.15 